\title{
Motives, Barriers, and Expected Benefits of ISO 14001 in the Agri-Food Sector
}

\author{
Rocio Carrillo-Labella ${ }^{1, *}$, Fatiha Fort ${ }^{2}$ (I) and Manuel Parras-Rosa ${ }^{1, *}$ \\ 1 Department of Business Organization, Marketing and Sociology, University of Jaen, 23071 Jaén, Spain \\ 2 SupAgro-MOISA, Department Marketing Management, University of Montpellier, 34000 Montpellier, \\ France; fatiha.fort@supagro.fr \\ * Correspondence: rlabella@ujaen.es (R.C.-L.); mparras@ujaen.es (M.P.-R.)
}

Received: 1 January 2020; Accepted: 12 February 2020; Published: 25 February 2020

\begin{abstract}
Over time, sustainability has gained a greater presence in companies and with consumers around the world, although it can be said that there is still some confusion in its conceptualization and in the identification of the driving factors. A part of the literature considers that environmental management systems (EMS) such as ISO 14001 are facilitating factors that allow organizational remodeling towards more sustainable production. For a better understanding, this paper presents a qualitative study with semi-structured interviews to analyze the perceptions that managers, employees, and quality managers have about the concept of sustainability and, given that environmental management systems are considered as motivational factors, it also analyzes the perceptions they have about the motivations, barriers, and expected benefits of their adoption in the olive food industry in southern Spain. It is possible to point out the existence of some confusion about the concept of sustainability, and that both regulatory and market factors such as image and reputation improvement, differentiation, and sales increases, especially in exports, are considered to be motivational for their implementation. This work contributes to the literature on sustainability and environmental management systems in sectors of activity with high environmental involvement, such as the agri-food industry.
\end{abstract}

Keywords: sustainability; environmental management systems; ISO 14001; agri-food sector; olive oil sector

\section{Introduction}

Over time, the concept of sustainability has gained greater presence and importance for administration, companies, and consumers. The concept, even today, is not entirely understood by companies, where there is some confusion about its conceptualization, especially in its environmental dimension [1]. However, there are ample studies that reflect a positive relationship between the adoption of eco-innovation and sustainability [2-4], considering eco-innovation as a priority antecedent of sustainability.

In this regard, several studies have found a positive relationship between environmental management systems (EMSs) and the adoption of eco-innovation in firms, especially in terms of organization and processes [4-9]. EMSs can be considered as facilitating and motivational factors for the adoption of eco-innovations in organizations [4,6,10-14], and over time EMSs have been considered as an initiative to help achieve the goals of sustainable development [15-17].

As far as EMSs are concerned, there are two widely accepted systems worldwide, the international standard ISO 14001 (created by the International Organization for Standardization-ISO) and the European Union regulation Eco-Management and Audit Scheme (EMAS). Both EMAS and ISO 14001 are voluntary systems that provide impartial third-party assurance of the correct management 
of environmental performance and can be considered as a set of standards adopted at a strategic and operational level that allow companies to properly comply with environmental standards by contributing in this way, specifically for the improvement of the environment [18]. In addition, both certifications are voluntary and environmental management allows for more positive economic [19] and environmental $[17,20-22]$ effects.

Numerous studies on the ISO 14001 standard have been conducted from a socio-ecological, environmental, or to a lesser degree, an economic perspective [17], however, few studies have focused on countries such as the USA, Spain, Japan, Canada, Germany, UK, China, Malaysia, Switzerland, and France (Figure 1). Spain is second on the list of countries for the number of ISO 14001 studies available. A literature review of the Web of Science and Scopus databases revealed that most of these studies are multisector analyses, with few specific studies on the industrial sector or services, and are mainly limited to the regions of Catalonia, Galicia, and the Basque Country (Figure 2). It was also noted, both in Spain and other parts of the world, that ISO 14001 studies of the agricultural sector are rare. In fact, only one study was found, located in southern Spain, and it adopts a financial approach [23] (Table 1).

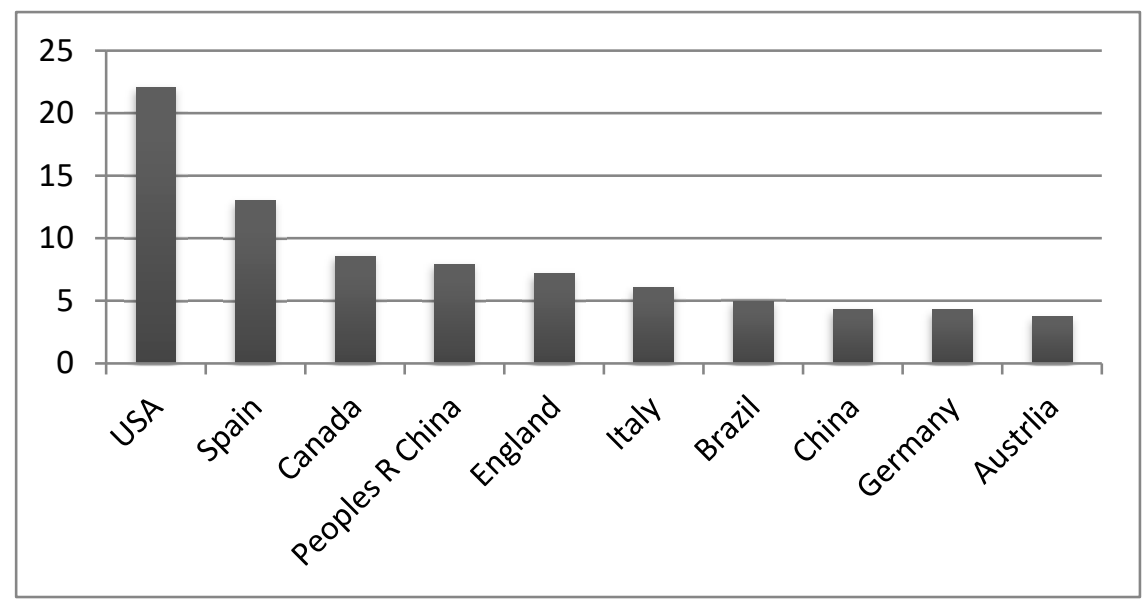

Figure 1. ISO 14001 studies and social sciences (Web of Science).

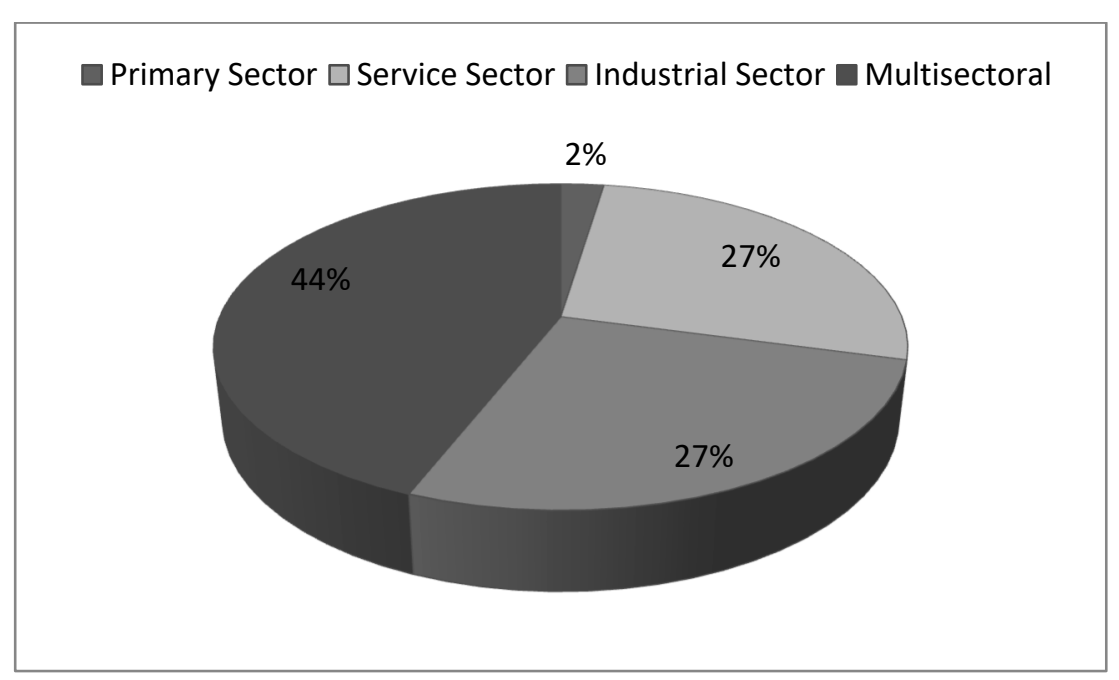

Figure 2. Global map of ISO 14001 studies in Spain. 
Table 1. Global map of studies in the agri-food sector (Web of Science and Scopus).

\begin{tabular}{|c|c|c|c|c|}
\hline Year & Country & Authors & Title & Review \\
\hline 2018 & Spain & Cavero-Rubio, J.A., Amores-Martinez, A. & $\begin{array}{l}\text { The eco-management and audit scheme (EMAS) environmental certification and its impacts on agricultural companies' } \\
\text { financial. }\end{array}$ & ITE-Información Técnica Económica Agraria. \\
\hline 2016 & Nigeria & Abah, R.C., Petja, B.M. & Assessment of potential impacts of climate change on agricultural development in the Lower Benue River Basin & Environmental Monitoring and Assessment \\
\hline 2015 & India & Singh, N., Jain, S., Sharma, P. & Motivations for implementing environmental management practices in Indian industries & Ecological Economics \\
\hline 2015 & Spain & $\begin{array}{l}\text { Guerrero-Baena, M.D., Gómez-Limón, J. } \\
\text { A., Fruet, J.V. }\end{array}$ & A multicriteria method for environmental management system selection: an intellectual capital approach & Journal of Cleaner Production \\
\hline 2013 & Brazil & $\begin{array}{l}\text { Trierweiller, A.C., Peixe, B.C.S., Tezza, R., } \\
\text { Bornia, A.C., Campos, L.M.S. }\end{array}$ & Measuring environmental management disclosure in industries in Brazil with Item Response Theory & Journal of Cleaner Production \\
\hline 2012 & Australia & Carruthers, G., Vanclay, F. & $\begin{array}{l}\text { The intrinsic features of Environmental Management Systems that facilitate adoption and encourage innovation in } \\
\text { primary industries }\end{array}$ & Journal of Environmental Management \\
\hline 2012 & Mexico & Blackman, A., Guerrero, S. & What drives voluntary eco-certification in Mexico? & Journal of Comparative Economics \\
\hline 2008 & Iran & Edalat, A. & $\begin{array}{l}\text { Implementation of ISO 14001: } 2004 \text { (environmental management system standard) for reverse osmosis desalination } \\
\text { plants for the first time in Iran }\end{array}$ & Desalination \\
\hline 2007 & France & Grolleau, G., Mzoughi, N., Thomas, A. & What drives agri-food firms to register for an Environmental Management System? & European Review of Agricultural Economics \\
\hline 2007 & Australia & Huhn, K.J., Seymour, E.J., Ridley, A.M. & Environmental Management Systems in the Australian lamb industry: challenges and opportunities for family farms & Australian Journal of Experimental Agriculture \\
\hline 2007 & Australia & Carruthers, G. & Using the EMS process as an integrative farm management tool & Australian Journal of Experimental Agriculture \\
\hline 2007 & Australia & Seymour, E.J., Ridley, A.M., Noonan, J. & $\begin{array}{l}\text { Assessing the role of a four-stage approach for improving the compatibility of Environmental Management Systems and } \\
\text { Quality Assurance }\end{array}$ & Australian Journal of Experimental Agriculture \\
\hline 2007 & Australia & Carruthers, G., Vanclay, F. & Enhancing the social content of environmental management systems in Australian agriculture & $\begin{array}{l}\text { International Journal of Agricultural Resources, } \\
\text { Governance and Ecology }\end{array}$ \\
\hline 2005 & Australia & $\begin{array}{l}\text { Story, P.G., Walker, P.W., McRae, H., } \\
\text { Hamilton, J.G. }\end{array}$ & $\begin{array}{l}\text { A Case Study of the Australian Plague Locust Commission and Environmental Due Diligence: Why Mere Legislative } \\
\text { Compliance Is No Longer Sufficient for Environmentally Responsible Locust Control in Australia }\end{array}$ & $\begin{array}{l}\text { Integrated Environmental Assessment } \\
\text { and Management }\end{array}$ \\
\hline 2004 & Canada & Yiridoe, E.K., Marett, G.E. & Mitigating the High Cost of ISO 14001 Standard Certification: Lessons from Agribusiness Case Research & $\begin{array}{l}\text { International Food and Agribusiness } \\
\text { Management Review }\end{array}$ \\
\hline 2003 & Canada & $\begin{array}{l}\text { Yiridoe, E., Clark, J., Marett, G., Gordon, } \\
\text { R., Duinker, P }\end{array}$ & ISO 14001 EMS standard registration decisions among Canadian organizations & Agribusiness and International Journal \\
\hline 2003 & Italy & $\begin{array}{l}\text { Marchettini, N., Panzieri, M., Niccolucci, } \\
\text { V., Bastianoni, S., Borsa, S. }\end{array}$ & $\begin{array}{l}\text { Sustainability indicators for environmental performance and sustainability assessment of the productions of four fine } \\
\text { Italian wines }\end{array}$ & $\begin{array}{l}\text { International Journal of Sustainable Development and } \\
\text { World Ecology }\end{array}$ \\
\hline 2003 & Australia & Carruthers, G., Tinning, G. & Where, and how, do monitoring and sustainability indicators fit into environmental management systems? & Australian Journal of Experimental Agriculture \\
\hline 2001 & Canada & Wall, E., Weersink, A., Swanton, C. & Agriculture and ISO 14000 & Food Policy \\
\hline 2001 & USA & Reith, C. & $\begin{array}{l}\text { Applying Environmental Management Strategies to the Agricultural Sector: Louisiana's Model Sustainable } \\
\text { Agricultural Complex }\end{array}$ & Corporate Environmental Strategy \\
\hline
\end{tabular}


Given the growing importance of sustainability and the contribution of EMS, and the rarity of studies on the Spanish agri-food sector, the objectives of this research are twofold: First, to analyze the perceptions that managers, employees, and those responsible for quality have about the concept of sustainability. Second, since environmental management systems are considered motivational factors, to analyze the perceptions that managers and employees have about the motivations, barriers, and expected benefits of their adoption. Within the agri-food sector, this study dwells on olive oil producing companies in southern Spain. ISO 14001 is the most widely accepted EMS in this sector, as approximately $25 \%$ of producers have chosen directly or indirectly to implement this standard. A similar percentage has been found in other agri-food studies from countries such as Australia [24] and also among firms in the rest of Europe [25]. ISO 14001 seems to be more popular than other schemes because it is more widely recognized at the international level [26].

This work is divided into five parts. In the first one, a literature review is carried out to identify the main motivations, barriers, and expected benefits of the adoption of the ISO 14001 standard. In the second part, the main objectives of the study and the methodology used are highlighted. In the third part, the main results are presented, while in the fourth part there is a discussion of the main results, and finally, the fifth part presents the conclusions, limitations, and potential for future research.

\section{Literature Review}

An in-depth review of the literature allowed us to identify the main motivational factors that drive organizations to implement ISO 14001, which are related to environmental regulations, the market, and/or the pursuit of better economic and environmental performance [5,27-38].

From an organizational perspective, the literature highlights the important role that pressure from managers and employees play in its implementation [26,39-44]. In a similar vein, a study of the French agri-food sector discusses the important role of human resources in the adoption of these environmental standards [29]. Other authors have identified the pressure exerted by power groups or stakeholders as a driver [24,45-49].

Moreover, from the same organizational perspective, many studies have found a relationship between ISO 14001 and quality standards such as ISO 9001, identifying the latter as a facilitator or antecedent of its implementation [5,14,25,49-51]. Both certificates allow for significant improvements, both from an organizational perspective, such as better efficiency, measured by cost savings, shorter delivery times, resource optimization, better management control, and improvements in employee results, measured by motivation satisfaction, and additionally from a market perspective, such as the improvement of customer satisfaction, improvement of image, improvement of the relationship with suppliers, and a better positioning in the market, among other factors [25,33,50,52-55]. Along these lines, a study conducted by Korean companies determined that the adoption of ISO 9001 positively affects the adoption of ISO 14001 [56], coinciding with other studies, such as those carried out by Portuguese companies [57] and the agri-food sector in France [29].

Another area of motivational factors identified is that of seeking to improve economic and financial performance [58-61] Several authors have found that ISO 14001 implementation is related to profit expectations $[24,62-65]$ and that differentiation from the competition via the standard could bring greater profitability to the firm [66]. Other authors [67] also concluded that ISO 14001 is beneficial for businesses in the long run in terms of profitability and market benefits.

Although the prevailing view in the literature is that EMSs foster and strengthen measures to improve the environmental and financial performance of businesses, some studies report more negative or at least inconclusive results $[68,69]$. Also, in the same area of financial and economic performance, another motivational factor found for adopting the standard is the cost savings. Several studies have concluded that firms with a pro-active environmental behavior have significantly greater control of their costs [42,70-74].

It is also important to highlight findings that show the motivational role of public administration towards environmental issues through the requirements of legal and regulatory compliance by 
companies. Various studies reveal that companies that perceive higher regulatory pressure are more likely to adopt environmental standards such as ISO $14001[19,33,38,56,58,75,76]$, although it should be noted that other authors state that regulatory compliance seems to not be the main motivation for its adoption [42].

Lastly, the literature review also suggests, albeit inconclusively, that market-related factors can act as a major motivational force in the adoption of the standard [77], giving companies a competitive edge $[78,79]$ in both internal and external markets through the drive to improve customer satisfaction [8] and the image and reputation of the organization $[6,32,34,38,43,71,80]$, as well as the agri-food sector as a whole [24,29].

Alongside building an image and reputation, an equally significant motivational factor in ISO 14001 adoption is the growing tendency for businesses to be more outward-looking and seek out new international markets and export opportunities $[17,24,81,82]$, together with the pressure exerted by distributors in this process $[43,76,83]$. The ISO 14001 standard can be a good marketing instrument for small and medium-sized firms [17] and a useful tool to facilitate access to sales opportunities, thus allowing firms to exploit the market benefits of both domestic and international markets $[32,67,71]$. In the case of Chinese firms, those that seek ISO 14001 certification are motivated by export regulations $[59,84,85]$, such as firms in Italy [34] and Portugal [57].

In the case of the agri-food sector, the authors have suggested [86] that ISO 14001 adoption is essential to success in international trade and, in keeping with this, others [23] have confirmed in their study of the olive oil sector that producers that export their product are more likely to adopt these environmental standards.

With regard to barriers to adoption, the literature identifies various aspects, such as the costs involved $[17,24,87,88]$, lack of knowledge of the standard, and a lack of skills and abilities required for its implementation [89], as well as difficulties in integrating these protocols into the organizational culture of firms [57,71]. Further barriers cited include excessive bureaucracy and paperwork [41,90,91], a lack of knowledge of environmental practices and techniques [32,92,93], a lack of resources and/or commitment on the part of the firm's executives, and the reluctance of employees and middle management $[40,91,92,94]$. We should, however, qualify the latter by pointing out, as mentioned above in the section describing motivations, that there is ample literature to show that managers and employees play a positive role in the adoption of EMSs [10,26,29,94].

In summary, after having completed the literature review, it can be said that there are organizational factors, namely, pressure from managers, employees, and stakeholders. Additionally, there are several factors that positively affect the adoption of ISO 14001 in organizations, namely, cost savings, better economic returns, greater benefits and profitability, adherence to regulations, exigencies and orientations of public administrations in environmental matters, market stimulation for internationalization, improvement of the image and reputation of the organization, greater customer satisfaction, and the improvement of positioning in the market. On the other hand, there are economic factors, such as the high cost of implementing the norm, increasing organizational knowledge of the norm, dealing with the lack of skills and abilities of human resources to implement it, resistance to its implementation, and procedural excessive bureaucracy that limits a greater extension of ISO 14001 in organizations.

Using the literature review as a springboard and considering the scarcity of ISO 14001 studies in the agricultural sector, this paper analyses the adoption of this environmental standard in the olive oil sector in Spain.

\section{Methodology and Study Aims}

Considering the review of the literature and the small number of studies in the agricultural sector, this work analyzes the olive oil-producing sector in southern Spain and the adoption of the ISO 14001 environmental standard. Within the Spanish olive oil market, approximately $80 \%$ of production and exports originate in the south of Spain (Andalusia), accounting for $40 \%$ of the world's production of olive oil. For this, the olive sector has about 844 oil mills or first-processing industries, of which $95 \%$ 
are small and medium-sized enterprises and approximately $20 \%$ have a direct or indirect form through second-grade cooperatives implementing the standard ISO 14001.

Given the importance of eco-innovation processes for the achievement of the sustainability of companies and the role that EMSs play in the process of change, also considering the scarcity of studies carried out in the olive oil industry, this study has two objectives. First, to analyze the perceptions that managers, employees, and those responsible for quality have about the concept of sustainability; since environmental management systems are considered as motivational factors for it, the second objective is to analyze the perceptions that executives and employees have about the expected motivations, barriers, and benefits of their adoption through a qualitative study with semi- structured interviews.

In order to answer these questions, the previous literature has mainly focused on analyzing the perceptions of general directors, senior managers, and operations managers; studies in which the opinions of employees have been considered are scarce [95], despite their role as key actors in the success of the adoption of the standard, as some authors have pointed out $[85,96,97]$. On the other hand, the methodology used in these works has been mostly quantitative, and qualitative studies are rare. This tendency to use a quantitative approach has important implications, as evidenced by the previous authors, since qualitative studies tend to focus on more diverse respondents (including employees and other stakeholders) and adopt a more critical and in-depth approach to the internalization of ISO 14001.

In this context, to make up for these limitations, this work analyzes the opinions of managers, employees, and managers from the quality department (seven managers, five quality managers, and eight employees), using a qualitative methodology to do so, consisting of interviewing 20 people, belonging to 20 companies of different sizes with different export orientations, through semi-structured interviews. In this way, a great diversity of types of organizations and the agents involved in their management is covered (Table 2). The field work was carried out between March and July 2019.

Table 2. Data collected by the authors.

\begin{tabular}{cc}
\hline Size of the Organization & $\mathbf{6}$ Microfirms, 8 Small, $\mathbf{6}$ Medium \\
\hline Export status & 10 exporters and 10 nonexporters. \\
& Microfirms: 3 exporters, 3 nonexporters \\
Export status/size & Small: 4 exporters, 5 nonexporters \\
& Medium: 3 exporters, 2 nonexporters. \\
Profile of person interviewed & 7 managers, 5 quality managers, 8 employees. \\
\hline
\end{tabular}

For the collection of information, given that the sector is mainly made up of small and medium-sized enterprises and supporting UE Regulation No. 651/2014, which contemplates the classification of companies, six microenterprises have been interviewed, along with eight small and six medium-sized companies. In addition, considering previous studies of the sector that have shown that companies with greater export orientations are more likely to adopt ISO 14001 [23], this has been considered in the extraction of the sample, analyzing companies that export and companies that do not export. In this regard, it should be noted that it has been difficult to find companies that have the standard in place and are not medium-sized export ones, and it has been considered, on the one hand, that companies now do not export as a result of the complexity of the markets but have instead stated that their intention is to export again. Companies that follow the standard but do not export directly do so through central sales or second-grade cooperatives.

The people interviewed were invited to state what they understood about sustainability and its practical application to their organization, together with the reasons that had led to the adoption of ISO 14001, the impediments and barriers found, as well as the identification of the real and expected benefits of their adoption. The average duration of an interview was $45 \mathrm{~min}$. The profiles of the interviewees according to the activity performed by the person interviewed within the company and the organization profile according to the size and export orientation are given in Table 3. 
Table 3. Profile of the people interviewed.

\begin{tabular}{|c|c|c|}
\hline Interview & Exporting Activity & Size of the Company \\
\hline $\mathrm{E} 1 *$ & Exporter & Microfirm \\
\hline E2 & No Exporter & Small \\
\hline E3 & Exporter & Medium \\
\hline $\mathrm{E} 4$ & Exporter & Microfirm \\
\hline E5 & No Exporter & Microfirm \\
\hline E6 & No Exporter & Small \\
\hline E7 & No Exporter & Small \\
\hline E8 & No Exporter & Medium \\
\hline M1 ** & Exporter & Small \\
\hline M2 & No Exporter & Medium \\
\hline M3 & Exporter & Microfirm \\
\hline M4 & No Exporter & Small \\
\hline M5 & Exporter & Small \\
\hline M6 & No Exporter & Small \\
\hline M7 & Exporter & Medium \\
\hline QM1 *** & Exporter & Small \\
\hline QM2 & Exporter & Medium \\
\hline QM3 & Exporter & Medium \\
\hline QM4 & No Exporter & Microfirm \\
\hline QM5 & No Exporter & Microfirm \\
\hline
\end{tabular}

${ }^{*}$ E: Employee; ${ }^{* *}$ M: Manager; ${ }^{* * *}$ QM: Quality Manager.

Of the different approaches used in qualitative research, in this work, thematic analysis has been used, followed by a description that makes clear how we have worked with the data and accounts for the process followed for the registration, systematization, recovery, understanding, and interpretation of the information collected during the development of the investigation. Thematic analysis is a method that allows one to identify, organize, and analyze in detail, and thereby provide patterns or themes determined from careful reading and rereading of the information collected, thus inferring results that propitiate the adequate understanding or interpretation of the studied phenomenon $[98,99]$. In addition, thematic analysis offers an exhaustive process to identify numerous cross-references between the issues that arise and all of the information, allowing one to link several concepts with the opinions of the participants and compare them with the data that have been saved in different situations at different times during the investigation [100].

Specifically, a thematic approach has allowed, before the collection of information, the definition of clear criteria, and forms of registration and systematization of the information have been established in order to organize the information compiled and produced in the development of the research, in order to guide the understanding or interpretation and make its recovery viable. In this work, the steps suggested by [99] have been followed, that is, a) transcription of the data and interviews, b) reading and reading, noting the initial ideas, c) identification of the interesting characteristics generated systematically throughout the dataset, i.e., the relevant ideas, d) identification of the issues based on the relevant data of each of the candidates, e) construction of a functional analysis table for each of the interviews, and f) cross-checking of each individual analysis, allowing for the identification of the main issues with respect to the objective sought.

\section{Main Results}

At this point, the main results are presented as four points, namely, (1) the degree of knowledge of the concept of sustainability in the agri-food olive industry, (2) the main motivations for the implementation of ISO 14001, (3) the difficulties encountered, and (4) the expected benefits of the adoption process (Table 4 ). 
Table 4. Analytical themes and subthemes.

\begin{tabular}{|c|c|c|c|}
\hline Themes & Subthemes & Number of Verbatim & Example of Verbatim \\
\hline \multirow{2}{*}{ 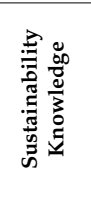 } & $\begin{array}{l}\text { Ignorance of the concept, i.e., only the } \\
\text { environmental dimension of it being } \\
\text { mentioned. }\end{array}$ & 15 & $\begin{array}{l}\text { Quality Manager (QM1): "Well, the company in the sector, compared to how we were } 20 \text { years ago, has improved in terms of the environment, for } \\
\text { example waste management." } \\
\text { Quality Manager (QM2): "Sustainability is very important for us. The environment is within the mission and vision of the company and is within the } \\
\text { strategy and policy of the company." }\end{array}$ \\
\hline & $\begin{array}{l}\text { Facilitating factor for the adoption of } \\
\text { eco-technologies and, as a consequence, } \\
\text { their contribution towards sustainability. }\end{array}$ & 6 & $\begin{array}{l}\text { Quality Manager (QM5): "When we made the new cooperative was when we decided to adopt the ISO } 14001 \text { standard. We hired a technician who was } \\
\text { saying what we had to do to get accredited and incorporate the new technologies needed for the standard in terms of water and waste." }\end{array}$ \\
\hline \multirow{5}{*}{ 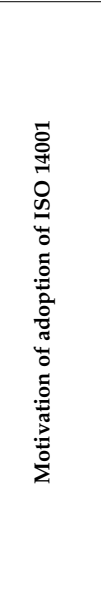 } & $\begin{array}{l}\text { ISO } 9001 \text { quality standards facilitating } \\
\text { factor for its implementation. }\end{array}$ & 10 & $\begin{array}{l}\text { Quality Manager (QM3): "First we implemented quality, and this has allowed us to improve order in the organization and has facilitated the adoption } \\
\text { of ISO } 14001 \text { following the advice of the certifiers. Now we are focused on quality, but little by little we have realized that the environment is } \\
\text { important too." }\end{array}$ \\
\hline & $\begin{array}{l}\text { Improvement of internal process } \\
\text { management and greater motivation and } \\
\text { training of employees. }\end{array}$ & 7 & $\begin{array}{l}\text { Employee (E6): "The truth is that we did not know anything about the environment and they are informing and advising you on how you should do it } \\
\text { and it makes your job easier because you know at every moment what you should do." }\end{array}$ \\
\hline & $\begin{array}{l}\text { As a guarantee for regulatory compliance } \\
\text { and improvement of environmental } \\
\text { behavior through the management and } \\
\text { control of waste and waste. }\end{array}$ & 10 & $\begin{array}{l}\text { Employee (E5): "In this sector, a lot of waste is generated, and must be controlled. Although there are many regulations, audits guarantee that we are } \\
\text { controlling this well, which gives us peace of mind." } \\
\text { Manager (M5): "What worries us is knowing whether we comply with environmental regulations, and this certification reassures us that we do well." }\end{array}$ \\
\hline & $\begin{array}{l}\text { Improve the quality and safety of } \\
\text { products in the production process. }\end{array}$ & 5 & $\begin{array}{l}\text { Employee (E7): "For the governing board, the issue of quality is very important. That is why the issue of phytosanitary collection is very important and } \\
\text { we have a clean point in the factory for the field's packaging, in addition, that is controlled by us in the audits." }\end{array}$ \\
\hline & $\begin{array}{l}\text { Market: Competitiveness; Product } \\
\text { differentiation; Improve the image and } \\
\text { reputation; Increase sales; Increase } \\
\text { export and access new markets; } \\
\text { Distribution pressure (large distributors } \\
\text { and importers); Greater benefits. }\end{array}$ & 20 & 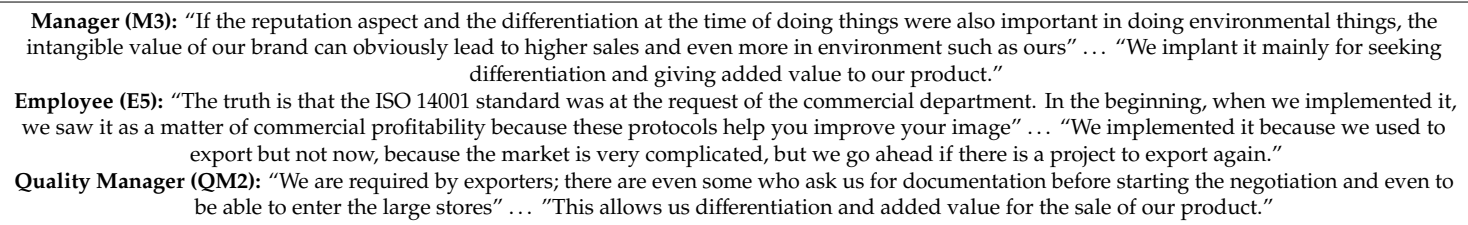 \\
\hline \multirow{2}{*}{ 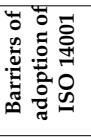 } & $\begin{array}{l}\text { Bureaucratic barriers such as excess } \\
\text { paperwork, adoption time, and audits. }\end{array}$ & 13 & $\begin{array}{l}\text { Manager (M5): "Investment, no; time needs, yes, because the documentation that is generated and the person who carries it, that in this case is the } \\
\text { teacher, because in terms of paperwork it takes a long time because it takes a lot of data. We spent two days auditing." }\end{array}$ \\
\hline & Initial costs and investment required. & 12 & $\begin{array}{l}\text { Quality Manager (QM4): "In the beginning, it is expensive because you have to make changes in the company, but we did it at the time we built the } \\
\text { new factory." }\end{array}$ \\
\hline 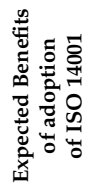 & $\begin{array}{l}\text { Increase sales and access to new } \\
\text { international markets. } \\
\text { Greater benefits } \\
\text { Better economic and financial results. }\end{array}$ & 15 & $\begin{array}{l}\text { Manager (M5): "For the certifications, you make an investment: what you are looking for is to sell and obtain greater benefits and profitability, that is } \\
\text { clear, here we are looking forward, here the partners make demands on us and they look for that, benefit and more benefit." } \\
\text { Employee (E6): "Benefits, in addition to collaborating with the environment, which is important for us, therefore, to improve the results of our product } \\
\text { in order to defend it in the market and obtain greater profitability." } \\
\text { Employee (E1): "Benefits? Let's economize? I do not know. Since I've been here, I have not seen changes ... rather the image, but I don't know ... it can } \\
\text { be more money but I don't Know" }\end{array}$ \\
\hline
\end{tabular}




\subsection{Sustainability Knowledge}

With respect to the knowledge of the concept of sustainability and the role that EMSs can play towards it, two themes have been extracted. First, there is a lack of knowledge about the concept of sustainability and its dimensions by the leaders employed and responsible for organizations, although it is true that those who have expressed some knowledge represent the largest and most export-oriented companies, and that they associate it with the obvious environmental dimension, and the social and economic aspects of the concept. This may suggest that the size and exportation of organizations plays an important role in the development of sustainability and in the adoption of environmental management systems.

Second, from a technological perspective, it has been possible to identify a relevant result for the process of change towards sustainability. All companies interviewed, regardless of size and export orientation, have stated that ISO 14001 has allowed them greater knowledge and the implementation of some clean and/or efficient technology along the product value chain, especially in production systems. They have stated not only that the information about eco-innovations comes to them from the suppliers, but also that the environmental technicians and reports received from the audits have guided them to those technological aspects that should be improved, thus avoiding greater pollution and the consumption of inputs such as energy and water.

\subsection{Main Motivations}

Regarding the motivations, five main themes have been identified. First, from an organizational perspective, all the people interviewed, regardless of the size of their organization and export orientation, have stated that the ISO 9001 quality standard has facilitated the implementation of the ISO 14001 environmental certification. All had previously implemented the ISO 9001 quality standard, except for two organizations that implemented both standards at the same time and one that was still located in the urban case and had previously adopted it to the ISO 9001 quality standard to guarantee compliance with environmental regulations regarding waste, fluids, and noise, aspects that they were very concerned about at their location.

We also note that all the people interviewed stated that the ISO 9001 standard has signified a new way of working and organizing the processes that has facilitated the implementation of the ISO 14001 environmental standards, together with those of the BRC and IFS food standards. In addition, two companies have indicated that they no longer officially hold the standard, although they continue to maintain the protocols, and another organization said they have replaced it with the ISO 22000 food safety standard, a standard that encompasses ISO 9001 and hazard analysis and critical control points (HACCP) analysis.

Second, from an organizational and human resources management perspective, all the people interviewed conclude that the ISO 14001 standard facilitates the way of working and supposes a greater effectiveness and efficiency in the management of productive processes and knowledge of human resources competencies. This is attributed to the fact that each employee knows that their skills facilitate the proper management of the environment. In this line, they state that the standard provides them with more information and trains them in environmental aspects, since sometimes they do not really know how they should manage it. In addition, it provides greater awareness for employees when working with environmental aspects.

Third, all managers, quality managers, and employees have expressed the great impact that this sector has on the environment with wastewater, sludge, and bone and leaf waste. All have attributed much importance to adopting the standard for greater control over the aforementioned waste and better compliance with environmental standards. They see ISO 14001 as an instrument that reassures them of environmental regulatory compliance.

Fourth, they perceive the norm as an instrument that improves the quality of products through greater control of production processes such as the collection and control of phytosanitary containers 
and packaging in the field. They state that some actions of the production process can affect the quality of products and that this control helps to improve quality.

Fifth, market factors are where all the people interviewed were seen to be most affected, and it can be emphasized that they perceive the norm as an instrument that can give them a competitive advantage. All managers expressed that the ISO 14001 standard allows them a strategy to differentiate their product and improve the image and reputation of their organization. Along the same lines, managers have expressed the current pressure to which they are subjected by distributors and exporters with respect to environmental compliance, and their belief that this ISO 14001 standard can facilitate access to international markets and negotiation with large export and distribution channels.

It should be noted that, among the no exporting companies, they state that accreditation helps to improve and prepare the organization for exportation, while others indicate that they followed the recommendations that second-grade cooperatives or sales centers have made to improve their image for exportation and to be able to sell. Along these lines, one of the people interviewed stated that he sees in the environmental aspects the present and the future of the market and that it can be a commercial opportunity if they focus on the segment of consumers that values these behaviors.

Finally, with respect to market and commercial aspects, all managers and employees, especially those belonging to the commercial department, perceive the norm as a differentiating element in the distribution and said that this standard can bring greater benefits and greater financial economic performance for the organization. However, some of the people interviewed stated that, although it is one of the objectives pursued with its adoption, it is not entirely clear that the rule allows them to improve results in their companies and so there is doubt about whether there is a positive relationship between ISO 14001 and the economic and financial performance of companies.

\subsection{Main Barriers}

With respect to the barriers, two issues have been identified. Firstly, managers of smaller companies have mentioned the costs that the standard incurs and the level of investment necessary for adoption. Secondly, all the employees interviewed have declared that the bureaucratic procedures are a barrier, citing excess paperwork, the time involved in its adoption, and the periodic audits to which they are subjected. In this line, it should be noted, as stated above, that employees have mentioned as a positive that the standard allows them to know what each of their competencies are and this facilitates their work with respect to the environment.

\subsection{Main Expected Benefits}

Finally, with respect to the perceived and expected benefits, the results show that all the organizations interviewed perceive that the standard can provide them with economic and financial benefits through a competitive advantage, and differentiation that can allow for the improvement of their image and reputation, in addition to greater access to foreign markets. It is not entirely clear if there is a direct relationship between ISO 14001 and the economic and financial performance of the organization.

\section{Discussion}

This paper analyzes the perceptions of managers, employees, and those responsible for quality in the agri-food olive industry in terms of the concept of sustainability, and, given the positive contribution of environmental management systems towards this concept, whether they know any motivations, barriers, or expected benefits for the adoption of the ISO 14001 standard. Our results show that enterprises have manifested a certain degree of ignorance about the concept of sustainability, which is associated with the environmental dimension. This supports the thesis that there is still confusion about its conceptualization in business circles. Only the largest and most export-oriented companies manifest greater knowledge, considering priority environmental aspects in their activity together with food security. This first result makes us think that sustainability is in an incipient phase in the olive 
food industry and that the size and export orientation of organizations plays an important role in the development of sustainability and the adoption of environmental management systems in the industry. This result is in line with other studies of the agri-food sector, such as a study conducted in France [29].

A broad base of the literature states that the adoption of eco-innovations is necessary for the remodeling of companies towards sustainability, and that, environmental management systems can play an important role as a facilitating element in the processes of adoption $[4,101]$. In this line, the interviewees perceive that ISO 14001 plays an informative role and that its implementation facilitates the adoption of clean and efficient technologies through technical advice or the results presented after the audits. This result is in accordance with another study in the primary industry [24], where the analysis of the role of environmental management systems such as ISO 14001 in the adoption of innovations concludes that the standard is a flexible management system that improves management decision-making and presents strong potential to overcome barriers for the adoption of innovations. A study carried out in European SMEs also suggests that environmental management systems can benefit companies by encouraging environmentally friendly technologies and waste management [102].

With regard to the motivational factors, barriers, and expected benefits identified by the people interviewed, market aspects were considered the most relevant, although they see ISO 9001 as a motivational element that facilitates the adoption of the environmental standard ISO 14001. Other standards are also considered to be important for the sector, such as the BRC and IFS food safety standards. Until recently, the sector was totally focused on quality, but recently there has been a shift towards environmental aspects, which may suggest that the ISO 9001 quality standard has been a facilitating element in this process, coinciding with studies carried out in various other countries $[25,29,50,103]$.

Another motivation for adoption is the perceptions that employees and managers have of the role of the norm in the management of internal processes, motivation, and the training of human resources. Employees perceive the standard as an instrument that facilitates the way they work and leads to greater efficiency and effectiveness in terms of the management of production processes and acquisition of skills, which facilitates the proper management of increasingly demanding environmental aspects. This may confirm the importance of the human resources standard. Many works have shown that the standard affects strategies to improve employee satisfaction and strategies to enhance employee growth and skill [104]. Some research has also shown the effects of environmental management systems on improving the quality of workplaces and employee morale and providing incentives for employee training [102].

As reflected in the literature, the desire to improve environmental performance $[57,105]$ is a motivational factor for ISO 14001 adoption. Additionally, given the importance for enterprises in terms of the management of waste and waste due to its toxicity, this study shows that these enterprises perceive the ISO 14001 standard as an instrument that allows them to improve their control. The standard is also perceived as a tool that facilitates and guarantees the execution and compliance of the environmental standard, coinciding with other studies. For example, a study carried out in food companies in Malaysia has pointed out the importance given to standard adoption for the reduction of environmental impacts [17]. Another study carried out on Polish companies identified the tendency to make "green changes" to improve environmental performance and comply with ecological regulations and eliminate the adverse impact of companies on the environment as driving elements for standard adoption [106]. A study carried out on automobile companies in Spain identified the main benefits of ISO 14001 to be environmental aspects such as the reduction of gas emissions, reduction of inputs such as energy, water, and materials, and better waste management and processing $[105,107]$. In the case of the agri-food sector, the same can be found in [24,29].

Another of the motivational factors for standard adoption is the market aspect, although there are studies that indicate that the environmental dimension prevails over the market aspect [57]. In this work, we show that the market dimension carries considerable weight, coinciding with other studies that indicate that the ISO 14001 standard is a good marketing tool [108]. In this context, adoption is 
motivated by the perception that ISO 14001 can lead to better business results for the company by improving its image and reputation in the market, which will allow them to differentiate and create greater competitiveness that can then lead to greater sales and access to foreign markets. These results coincide with various existing studies $[17,34,95,105,106]$.

Although the barriers found in the literature are diverse, our results highlight just two main barriers. On the one hand are the costs of management and implementation; on the other hand are the bureaucratic procedures, paperwork, and the time for the adoption and execution of periodic audits. Finally, the benefits expected from standard adoption are differentiation that will give enterprises greater sales and access to new markets, and better economic and financial performance.

\section{Conclusions and Future Research}

This research aimed to analyze the perceptions that managers, employees, and quality managers of the olive food industry have regarding the concept of sustainability, as well as to identify the main motivations, barriers, and expected benefits of adopting ISO 14001. With respect to the first objective, we can conclude that there is a lack of knowledge of the concept of sustainability in its three dimensions, showing an association of the concept only with the environmental dimension. In addition, the standard indirectly plays a positive role towards sustainability by supporting the remodeling and change of organizations towards the adoption of clean and efficient technologies, as revealed in the literature [101]. This can be attributed to the concern they have expressed about reducing and avoiding certain polluting aspects such as water consumption, energy, emissions, or waste management.

With respect to motivational factors, the previous adoption of other standards such as ISO 9001 has been identified as facilitating the implementation of other standards such as ISO 14001. In addition, with respect to human resources, the norm is perceived as an element that improves the efficiency and productivity of the productive processes by having well-defined protocols. The environmental performance supposes greater training and information about environmental aspects, treatment, and improvements, along with greater motivation in the performance of their environmental activities and a greater knowledge of their responsibilities and competences at work.

Our findings suggest that companies see the norm as an instrument that guarantees compliance with environmental norms and support in the reduction of polluting actions such as waste management, allowing for an improvement in the quality of processes and products. They perceive the norm as a marketing tool that can lead to good commercial results through differentiation and thereby improve the image and reputation of the company, which can make them more competitive in the market by increasing their sales, mainly in the export markets. The standard is also considered as a tool that could facilitate trade negotiation and overcome some of the barriers that they face with large retailers, especially large international retailers and importers that are increasingly demanding greater environmental awareness [17,27].

With regard to the barriers, although the literature notes several obstacles to the adoption of ISO 14001, our results have found that the costs of adoption, especially the cost involved in its implementation and in terms of personnel in conducting audits and dealing with paperwork and bureaucracy, both in the activity and in the audits, present significant barriers. However, ISO 14001 improves and guarantees the sustainability of the olive oil value chain. In this sense, to improve these bureaucratic aspects and lessen the paperwork involved in the certification process, a future solution can be based on secure, transparent, digital platforms, as is the case with blockchain, which is a technique that is already used to assess the traceability of olive oil. This can be used to generate more confidence in all the links of the olive oil value chain [109].

It should be noted that, from a commercial perspective, the standard is an instrument that can lead to greater sales and commercial results, thus opening up new lines of research in the agri-food industry. It is not entirely clear, however, that there is a direct relationship between the adoption of the standards and some economic and financial outcomes $[68,110]$. 
Despite some limitations of this research in terms of its external validity, given the contingent nature of the context and the sample, we believe that it sheds light on perceptions and therefore on the adoption of environmental standards in a major sector of activity in Spain. In order to strengthen the validity of this research, we propose a continued analysis of the links between the adoption of the standard and the financial results of companies. Therefore, we propose deepening this research, supported in this case by financial statements of the organization in order to validate the results of studies based on the perceptions and opinions of experts and to identify whether or not there is a relationship between the adoption of the ISO 14001 and the aspects considered.

Author Contributions: Conceptualization, R.C.-L., F.F. and M.P.-R.; Formal analysis, R.C.-L.; Investigation, R.C.-L.; Methodology, R.C.-L.; Supervision, F.F. and M.P.-R.; Writing—original draft, R.C.-L.; Writing—review \& editing, R.C.-L., F.F. and M.P.-R. All authors have read and agreed to the published version of the manuscript.

Acknowledgments: We are grateful for the contributions and comments made by Michel Simioni, Senior Research in French National Research Institute for Agriculture, Food and the Environment (INRAE) and the contributions made so the researcher Alma López Aviles, who belongs to the center of environment and sustainability, University of Surrey, UK. with the purpose of improve the results of this investigation.

Funding: This research received no external funding.

Conflicts of Interest: The authors declare no conflict of interest.

\section{References}

1. Carrillo-Hermosilla, J.; Gonzales, P.D.R.; Könnölä, T. Eco-Innovation: When Sustainability and Competitiveness Shake Hands, 1st ed.; Palgrave Macmillan: New York, NY, USA, 2009.

2. Behnam, S.; Cagliano, R. Be sustainable to be innovative: An analysis of their mutual reinforcement. Sustainability 2017, 9, 17. [CrossRef]

3. Rennings, K. Redefining innovation-eco-innovation research and the contribution from ecological economics. Ecol. Econ. 2000, 32, 319-332. [CrossRef]

4. Rennings, K.; Ziegler, A.; Ankele, K.; Hoffmann, E. The influence of different characteristics of the EU environmental management and auditing scheme on technical environmental innovations and economic performance. Ecol. Econ. 2006, 57, 45-59. [CrossRef]

5. Daddi, T.; Testa, F.; Frey, M.; Iraldo, F. Exploring the link between institutional pressures and environmental management systems effectiveness: An empirical study. J. Environ. Manag. 2016, 183, 647-656. [CrossRef]

6. Frondel, M.; Horbach, J.; Rennings, K. What triggers environmental management and innovation? Empirical evidence for Germany. Ecol. Econ. 2008, 66, 153-160. [CrossRef]

7. Horbach, J. Determinants of environmental innovation-new evidence from German panel data sources. Res. Policy 2008, 37, 163-173. [CrossRef]

8. Horbach, J.; Rammer, C.; Rennings, K. Determinants of eco-innovations by type of environmental impact -The role of regulatory push/pull, technology push and market pull. Ecol. Econ. 2012, 78, 112-122. [CrossRef]

9. Rehfeld, K.; Rennings, K.; Ziegler, A. Determinants of environmental product innovations and the role of integrated product policy-an empirical analysis. Ecol. Econ. 2007, 61, 91-100.

10. Babakri, K.A.; Bennett, R.A.; Franchetti, M. Critical factors for implementing ISO 14001 standard in United States industrial companies. J. Clean. Prod. 2003, 11, 749-752. [CrossRef]

11. Del Río, P.; Peñasco, C.; Romero-Jordán, D. What drives eco-innovations? A critical review of the empirical literature based on econometric methods. J. Clean. Prod. 2016, 112, 2158-2170.

12. Derimel, P.; Kesidou, E. Stimulating different types of eco-innovation in the UK: Government policies and firm motivations. Ecol. Econ. 2011, 70, 1546-1557.

13. Kesidou, E.; Derimel, P. On the Drivers of eco-innovations: Empirical evidence from the UK. Res. Policy 2012, 41, 862-870. [CrossRef]

14. Pereira-Moliner, J.; Claver-Cortés, E.; Molina-Azorín, J.F.; Tarí, J.J. Quality management, environmental management and firm performance: Direct and mediating effects in the hotel industry. J. Clean. Prod. 2012, 37, 82-92. [CrossRef] 
15. Ferenhof, H.A.; Vignochi, L.; Selig, P.M.; Rojas-Lezana, A.G.; Campos, L. Environmental management systems in small and medium-sized enterprises: An analysis and systematic review. J. Clean. Prod. 2014, 74, 44-53. [CrossRef]

16. Martínez-Perales, S.; Ortiz-Marcos, I.; Ruiz, J.J.; Lázaro, F.J. Using certification as a tool to develop sustainability in Project management. Sustainability 2018, 10, 1408. [CrossRef]

17. Salim, H.K.; Padfield, R.; Lee, C.T.; Syayuti, K.; Papargyropoulou, E.; Tham, M.H. An investigation of the drivers, Barriers, and incentives for environmental management systems in the Malaysian food and beverage industry. Clean Technol. Environ. 2018, 20, 529-538. [CrossRef]

18. Álvarez-Garcia, J.; Del Río-Rama, C.; Saraiva, M.; Ramos-Pires, A. The influence of motivations and barriers in the benefits. An empirical study of EMAS certified business in Spain. J. Clean. Prod. 2018, 185, 62-74. [CrossRef]

19. Frondel, M.; Horbach, J.; Rennings, K. End-of-piper or cleaner production? An empirical comparison of environmental innovation decisions across OECD countries. Bus. Strat. Environ. 2007, 16, 571-584. [CrossRef]

20. De Vries, H.J.; Bayramoglu, D.K.; Wiele, T.; Van der Wiele, T. Business and environmental impact of ISO 14001. Int. J. Qual. Reliab. Manag. 2012, 29, 425-435. [CrossRef]

21. Nawrocka, D.; Parker, T. Finding the connection: Environmental management systems and environmental performance. J. Clean. Prod. 2009, 17, 601-607. [CrossRef]

22. Zhang, W.; Wang, W.; Wang, S. Environmental performance evaluation of implementing EMS (ISO 14001) in the coating industry: Case study of a Shanghai coating firm. J. Clean. Prod. 2014, 64, 205-217. [CrossRef]

23. Guerrero-Baena, M.D.; Gómez-Limón, J.A.; Fruet, V. A multicriteria method for environmental management system selection: An intellectual capital approach. J. Clean. Prod. 2015, 105, 428-437. [CrossRef]

24. Carruthers, G.; Vanclay, F. The intrinsic features of environmental management systems that facilitate adoption and encourage innovation in primary industries. J. Environ. Manag. 2012, 110, 125-134. [CrossRef] [PubMed]

25. Heras-Saizarbitoria, I.; Boiral, O. ISO 9001 and ISO 14001: Towards a research agenda on management system standards. Int. J. Manag. Rev. 2013, 15, 47-65. [CrossRef]

26. Heras-Saizarbitoria, I.; Arana-Landín, G.; Molina-Azorín, J.A. Do drivers matter for the benefits of ISO 14001 ? Int. J. Oper. Prod. Manag. 2011, 31, 192-215. [CrossRef]

27. Darnall, N. Why firms mandate ISO 14001 certification. Bus. Soc. 2006, 45, 354-381. [CrossRef]

28. Ferrón-Vilchez, V. Does symbolism benefit environmental and business performance in the adoption of ISO 14001? J. Environ. Manag. 2016, 183, 882-894. [CrossRef]

29. Grolleau, G.; Mzoughi, N.; Thomas, A. What drives agri-food firms to register for an environmental management system? Eur. Rev. Agric. Econ. 2007, 34, 233-255. [CrossRef]

30. Heras-Saizarbitoria, I.; Arana, G.; Boiral, O. Exploring the dissemination of environmental certifications in high and low polluting industries. J. Clean. Prod. 2015, 89, 50-58. [CrossRef]

31. Jacobs, B.W.; Singhal, V.R.; Subramanian, R. An empirical investigation of environmental performance and the market value of the firm. J. Oper. Manag. 2010, 28, 430-441. [CrossRef]

32. Massoud, M.A.; Makarem, N.; Ramadan, W.; Nakkash, R. Environmental management practices in the Lebanese pharmaceutical industries: Implementation strategies and challenges. Environ. Monit. Assess. 2015, 187, 107. [CrossRef] [PubMed]

33. Mazzi, A.; Toniolo, S.; Mason, M.; Aguiari, F.; Scipioni, A. What are the benefits and difficulties in adopting an environmental management system? The opinion of Italian organizations. J. Clean. Prod. 2016, 139, 873-885. [CrossRef]

34. Murmura, F.; Liberatore, L.; Bravi, L.; Casolani, N. Evaluation of Italian Companies' Perception about ISO 14001 and Eco Management and Audit Scheme III: Motivations, Benefits and Barriers. J. Clean. Prod. 2018, 174, 691-700. [CrossRef]

35. Neugebauer, F. EMAS and ISO 14001 in the German industry- complements or substitutes? J. Clean. Prod. 2012, 37, 249-256. [CrossRef]

36. Prajogo, D.; Tang, A.K.; Lai, K.H. Do firms get what they want from ISO 14001 adoption? An Australian perspective. J. Clean. Prod. 2012, 33, 117-126. [CrossRef]

37. Prajogo, D.; Tang, A.K.Y.; Lai, K.H. The diffusion of environmental management system and its effect on environmental management practices. Int. J. Oper. Prod. Manag. 2014, 34, 565-585. [CrossRef] 
38. Singh, N.; Jain, S.; Sharma, P. Motivations for implementing environmental management practices in Indian industries. Ecol. Econ. 2015, 109, 1-8. [CrossRef]

39. Alt, E.; Díez-de-Castro, E.P.; Lloréns-Montes, F.J. Linking Employee Stakeholders to environmental performance: The role of proactive environmental strategies and shared vision. J. Bus. Ethics 2015, 128, 167-181. [CrossRef]

40. Boiral, O. Corporate greening through ISO 14001: A rational myth? Organ. Sci. 2007, 18, 127-146. [CrossRef]

41. Boiral, O. Managing with ISO systems: Lessons from practice. Long Range Plan. 2011, 44, 197-220. [CrossRef]

42. Diaz de Junguitu, A.; Allur, E. The adoption of environmental management systems based on ISO 1401, EMAS and alternative models for SME's: A qualitative empirical study. Sustainability 2019, 11, 7015. [CrossRef]

43. Djekic, I.; Rajkovic, A.; Tomic, N.; Smigic, N.; Radovanovic, R. Environmental management effects in certified Serbian food companies. J. Clean. Prod. 2014, 76, 196-199. [CrossRef]

44. Kaur, H. Impact of human resource factors on perceived environmental performance: An empirical analysis of a sample of ISO 14001 EMS companies in Malaysia. J. Sustain. Dev. 2011, 4, 188-211. [CrossRef]

45. Ferrón-Vílchez, V.; Darnall, N.; Aragón-Correa, J.A. Stakeholder influences on the firms' environmental practices. J. Clean. Prod. 2017, 142, 3370-3381. [CrossRef]

46. González-Benito, J.; Lannelongue, G.; Queiruga, D. Stakeholders and environmental management systems: A synergistic influence on environmental imbalance. J. Clean. Prod. 2011, 19, 1622-1630. [CrossRef]

47. Qi, G.Y.; Zeng, S.X.; Tam, C.M.; Yin, H.T.; Wu, J.F.; Dai, Z.H. Diffusion of ISO 14001 environmental management systems in China: Rethinking on stakeholders' roles. J. Clean. Prod. 2011, 19, 1250-1256. [CrossRef]

48. Testa, F.; Boiral, O.; Iraldo, F. Internationalization practices and institutional complexity: Can stakeholder's pressures encourage green washing? J. Bus. Ethics 2018, 147, 287-307. [CrossRef]

49. Zhu, Q.; Cordeiro, J.; Sarkis, J. Institutional pressures, dynamic capabilities and environmental management systems: Investigation the ISO 9001 environmental management system implementation linkage. J. Environ. Manag. 2013, 114, 232-242. [CrossRef]

50. Bernardo, M.; Simon, A.; Tarí, J.J.; Molina-Azorín, J.F. Benefits of management systems integration: A literature review. J. Clean. Prod. 2015, 94, 260-267. [CrossRef]

51. Corbett, L.M.; Cutler, D.J. Environmental management systems in the New Zealand plastics industry. Int. J. Oper. Prod. Manag. 2000, 20, 204-224. [CrossRef]

52. Allur, E.; Heras-Saizarbitoria, I.; Boiral, O.; Testa, F. Quality and environmental management linkage: A review of the literature. Sustainability 2018, 19, 4311. [CrossRef]

53. Delmas, M.; Montiel, I. The diffusion of voluntary international management standards: Responsible Care, ISO 9000, and ISO 14001 in the chemical industry. Policy. Stud. J. 2008, 36, 65-93. [CrossRef]

54. Delmas, M.; Montes-Sancho, M.J. An institutional perspective on the diffusion of international management system standards: The case of environmental management standard ISO 14001. Bus. Ethics Quart. 2011, 21, 103-132. [CrossRef]

55. Karapetrovic, S.; Casadesús, M. Implementing environmental with other standardized management systems: Scope, sequence, time and integration. J. Clean. Prod. 2009, 17, 533-540. [CrossRef]

56. Baez, K. The Diffusion of Voluntary Environmental Programs: The Case of ISO 14001 in Korea, $1996-2011$. J. Bus. Ethics 2017, 145, 325-336.

57. Santos, G.; Rebelo, M.; Lopes, N.; Alves, M.R.; Silva, R. Implementing and certifying ISO 14001 in Portugal: Motives, difficulties and benefits after ISO 9001 certification. Total Qual. Manag. Bus. 2016, 27, 1211-1223. [CrossRef]

58. Gavronski, I.; Ferrer, G.; Paiva, E.L. ISO 14001 certification in Brazil: Motivations and benefits. J. Clean. Prod. 2008, 16, 87-94. [CrossRef]

59. He, W.; Liu, C.; Lu, J.; Cao, J. Impacts of ISO adoption on firm performance: Evidence from China. China Econ. Rev. 2015, 32, 43-56. [CrossRef]

60. Schylander, E.; Martinuzzi, A. ISO 14001 - experiences, effects and future challenges: A national study in Austria. Bus. Strat. Environ. 2007, 16, 133-147. [CrossRef]

61. Zutshi, A.; Sohal, A. Environmental management system adoption by Australasian organizations: Part 1: Reasons, benefits and impediments. Technovation 2004, 24, 335-357. [CrossRef]

62. Cavero-Rubio, J.A.; Amores-Martinez, A. The Eco-Management and Audit Scheme (EMAS) environmental certification and its impact on agricultural companies' financial performance. ITEA Econ. Tech. Inf. Agric. 2017, 113, 287-305. 
63. Link, S.; Naveh, E. Standardization and discretion: Does the environmental standard ISO 14001 lead to performance benefits? IEEE Trans. Eng. Manag. 2006, 53, 508-519. [CrossRef]

64. Martin-de Castro, G.; Amores-Salvadó, J.; Navas-López, J.E. Environmental management systems and firm performance: Improving firm environmental policy through stakeholder engagement. Corp. Soc. Responsib. Environ. Manag. 2016, 23, 243-256. [CrossRef]

65. Wahba, H. Does the market value corporate environmental responsibility? An empirical examination. Corp. Soc. Responsib. Environ. Manag. 2008, 15, 89-99. [CrossRef]

66. Da Silva, R.V.; Teixeira, N. Environmental Business strategy: The Portuguese case. Bus. Strat. Environ. 2008, 17, 208-218. [CrossRef]

67. Lee, S.; Noh, Y.; Choi, D.; Rha, J.S. Environmental Policy Performances for Sustainable Development: From the Perspective of ISO 14001 Certification. Corp. Soc. Responsib. Environ. Manag. 2017, 24, 108-120. [CrossRef]

68. Heras-Saizarbitoria, I.; Molina-Azorín, J.F.; Gavin, P.M. ISO 14001 certification and financial performance: Selection-effect versus treatment-effect. J. Clean. Prod. 2011, 19, 1-12. [CrossRef]

69. Jong, P.; Paulraj, A.; Blome, C. The financial impact of ISO 14001 certification: Top-line, botton-line or both? J. Bus. Ethics 2014, 119, 131-149. [CrossRef]

70. Curkovic, S.; Sroufe, R.; Melnyk, S. Identifying the factors which affect the decision to attain ISO 14001. J. Energy 2005, 30, 1387-1407. [CrossRef]

71. Fryxell, G.E.; Lo, C.; Chung, S. Influence of motivations for seeking ISO 14001 certification on perceptions of EMS effectiveness in China. Environ. Manag. 2004, 33, 239-251. [CrossRef]

72. Massoud, M.A.; Fayad, R.; El-Fadel, M.; Kamleh, R. Drivers, barriers and incentives to implementing environmental management systems in the food industry: A case of Lebanon. J. Clean. Prod. 2010, 18, 200-209. [CrossRef]

73. Morris, A.S. ISO 14000 Environmental Management Standards: Engineering and Financial Aspects; John Wiley: Hoboken, NJ, USA, 2003.

74. Padma, P.; Ganesh, L.; Rajendran, C. A study on the ISO 14000 certification and organizational performance of Indian manufacturing firms. Benchmark. Int. J. 2008, 15, 73-100. [CrossRef]

75. Berliner, D.; Prakash, A. Public Authority and private rules: How domestic regulatory institutions shape the adoption of global private regimes. Int. Stud. Q. 2014, 58, 793-803. [CrossRef]

76. McGuire, W. The effect of ISO 14001 on environmental regulatory compliance in China. Ecol. Econ. 2014, 105, 254-264. [CrossRef]

77. De Durana, D.D.J.G. Voluntary Business Regulation and the Environment: Analysis of the Adoption of ISO 14001 in the Organizations of the CAPV. Ph.D. Thesis, University of the Basque Country, Leioa, Spain, 2014.

78. González-Benito, J.; González-Benito, O. An analysis of the relationship between environmental motivations and ISO 14001 certification. Br. J. Manag. 2005, 16, 133-148. [CrossRef]

79. Segarra-Oña, M.; Peiró-Signes, A.; Miret-Pastor, L.; Albors-Garrigós, J. Uncovering non-obvious relationship between environmental certification and economic performance at the food industry. Environ. Sci. Technol. 2011, 3, 325-338.

80. Tan, L. Implementing ISO 14001: Is it beneficial for firms in newly industrialized Malaysia? J. Clean. Prod. 2005, 13, 397-404. [CrossRef]

81. Junquera, B.; Del Brío, J.A.; Fernándes, E. Clients' involvement in environmental issues and organizational performance in businesses: An empirical analysis. J. Clean. Prod. 2012, 32, 288-298. [CrossRef]

82. Tuppura, A.; Toppinen, A.; Puumalainen, K. Forest certification and ISO 14001: Current state and motivation in forest companies. Bus. Strat. Environ. 2016, 25, 355-368. [CrossRef]

83. Liu, X.; Liu, B.; Shishime, T.; Yu, Q.; Bi, J.; Fujitsuka, T. An empirical study on the driving mechanism of proactive corporate environmental management in China. J. Environ. Manag. 2010, 91, 1707-1717. [CrossRef]

84. Qi, G.; Zeng, S.; Li, X.; Tam, C. Role of internationalization process in defining the relationship between ISO 14001 certification and corporate environmental performance. Corp. Soc. Responsib. Environ. Manag. 2012, 19, 129-140. [CrossRef]

85. Zeng, S.X.; Tam, C.M.; Tam, V.W.Y.; Deng, Z.M. Towards implementation of ISO 14001 environmental management system in selected industries in China. J. Clean. Prod. 2005, 13, 645-656. [CrossRef]

86. Wall, E.; Weersink, A.; Swanton, S. Agricultural and ISO 14001. Food Policy 2001, 26, 35-48. [CrossRef]

87. Bansal, P.; Bogner, W.C. Deciding on ISO 14001: Economics, institutions, and context. Long Range Plan. 2002, 35, 269-290. [CrossRef] 
88. De Oliveira, O.J.; Serra, J.R.; Salgado, M.E. Does ISO 14001 work in Brazil? J. Clean. Prod. 2010, 18, 1797-1806. [CrossRef]

89. Paillé, P.; Chen, Y.; Boirla, O.; Jin, J. The impact of human resource management on environmental performance: An employee-level study. J. Bus. Ethics 2014, 121, 451-466. [CrossRef]

90. Ivanova, A.; Gray, J.; Sinha, K. Towards a unifying theory of management standard implementation: The case of ISO 9001/ISO 14001. Int. J. Oper. Prod. Manag. 2014, 34, 1269-1306. [CrossRef]

91. Turk, A.M. ISO 14000 environmental management system in construction: An examination of its application in Turkey. TQM 2009, 20, 713-733. [CrossRef]

92. Alemagi, D.; Oben, P.M.; Ertel, J. Implementing environmental management systems in industries along the Atlantic coast of Cameroon: Drivers, benefits and barriers. Corp. Soc. Responsib. Environ. Manag. 2006, 13, 221-232. [CrossRef]

93. Curkovic, S.; Sroufe, R. Using ISO 14001 to promote a sustainable supply chain strategy. Bus. Strat. Environ. 2011, 20, 71-93. [CrossRef]

94. Psomas, E.L.; Fotopoulos, C.V.; Kafetzopoulos, D.P. Motives, difficulties and benefits in implementing the ISO 14001 environmental management system. Manag. Environ. Qual. Int. J. 2011, 22, 502-521. [CrossRef]

95. Boiral, O.; Guillaumie, L.; Heras-Saizarbitoria, I. Adoption and outcomes of ISO 14001: A systematic review. Int. J. Manag. Rev. 2018, 20, 411-432. [CrossRef]

96. Kitazawa, S.; Sarkis, J. The relationship between ISO 14001 and continuous source reduction programs. Int. J. Oper. Prod. Manag. 2000, 20, 225-248. [CrossRef]

97. Sambasivan, M.; Fei, N.Y. Evaluation of critical success factors of implementation of ISO 14001 using analytic hierarchy process (AHP): A case study from Malaysia. J. Clean. Prod. 2008, 16, 1424-1433. [CrossRef]

98. Berg, B.L. An introduction to content analysis, Qualitative Research Methods for the Social Sciences, 7th ed.; Allyn and Bacon: Boston, MA, USA, 2014.

99. Braun, N.; Clarke, V. Using thematic analysis in psychology. Qual. Res. Psychol. 2006, 3, 77-101. [CrossRef]

100. Alhojailan, M.I. Thematic analysis: A critical review of its process and evaluation. In Proceedings of the West East Institute International Academic Conference Proceeding, Zafreb, Croatia, 14-17 October 2012.

101. Hojnik, J.; Ruzzier, M. What drives eco-innovation? A review of an emerging literature. Environ. Innov. Soc. Transit. 2016, 19, 31-41. [CrossRef]

102. Zorpas, A. Environmental management systems as sustainable tools in the way of life for the SMEs and VSMEs. Bioresour. Technol. 2010, 101, 1544-1557. [CrossRef]

103. Pipatprapa, A.; Huang, H.; Huang, H. A novel environmental performance evaluation of Thailand's food industry using structural equation modeling and fuzzy analytic hierarchy techniques. Sustainability 2017, 8 , 246. [CrossRef]

104. Chiarini, A. Setting Strategies outside a Typical Environmental Perspective Using ISO 14001 Certification. Bus. Strat. Environ. 2017, 26, 844-854. [CrossRef]

105. Martín-Peña, M.L.; Díaz-Garrido, E.; Sánchez-López, J.M. Analysis of benefits and difficulties associated with firms' environmental management systems: The case of the Spanish automotive industry. J. Clean. Prod. 2014, 70, 220-230. [CrossRef]

106. Kudlak, R. Drivers of Corporate Environmentalism: The Case of the Polish Economy in Transition. J. Clean. Prod. 2017, 142, 3194-3203. [CrossRef]

107. Hasan, M.; Chan, C.K. ISO 14000 and its perceived impact on corporate performance. Bus. Manag. Horiz. 2014, 2, 1-14. [CrossRef]

108. Salim, H.K.; Padfield, R.; Yuzir, A.; Mohamad, S.E.; Kaida, N.; Papargyropoulou, E.; Nakamura, S. Evaluating the organizational intention to implement an environmental management systems: Evidence from the Indonesian food and beverage industry. Bus. Strat. Environ. 2018, 27, 1-14. [CrossRef]

109. Nikolakis, W.; John, L.; Krishnan, H. How Block chain can shape sustainable global value chains: An evidence, verifiability and enforceability (EVE) framework. Sustainability 2018, 10, 3926. [CrossRef]

110. Cañón de Francia, J.; Garcés-Ayerbe, C. ISO 14001 Environmental Certification: A Sign Valued by the Market? Environ. Resour. Econ. 2009, 44, 245-262. [CrossRef]

(C) 2020 by the authors. Licensee MDPI, Basel, Switzerland. This article is an open access article distributed under the terms and conditions of the Creative Commons Attribution (CC BY) license (http://creativecommons.org/licenses/by/4.0/). 